\title{
Functional Changes after Pancreatoduodenectomy: Diagnosis and Treatment
}

\author{
T.C. Khe Tran ${ }^{\mathrm{a}}$ Jan J.B. van Lanschot ${ }^{\mathrm{a}}$ Marco J. Bruno ${ }^{\mathrm{b}}$ Casper H.J. van Eijck ${ }^{\mathrm{a}}$ \\ Departments of a Surgery and ${ }^{\mathrm{b}}$ Gastroenterology and Hepatology, Erasmus Medical Center, \\ Rotterdam, The Netherlands
}

\section{Key Words}

Pancreatoduodenectomy - Functional changes - Delayed

gastric emptying $\cdot$ Endocrine and exocrine pancreatic

insufficiency · Enteric-coated capsules - Quality of life

\begin{abstract}
Relatively little is known about the gastrointestinal function after recovery of a pancreatoduodenectomy. This review focuses on the functional changes of the stomach, duodenum and pancreas that occur after pancreatoduodenectomy. Although the mortality in relation to pancreatoduodenectomy has decreased over the years, it remains associated with considerable morbidity, which occurs in $40-60 \%$ of patients. Physical complaints early after the operation are often caused by motility disorders, in particular delayed gastric emptying, which occurs in up to $40 \%$ of patients. During longer follow-up of these patients the occurrence of endocrine and exocrine pancreatic insufficiency becomes more predominant. Diabetes mellitus develops in $20-50 \%$ of patients after a pancreatic resection (pancreatogenic diabetes). The main presenting symptoms of exocrine insufficiency are weight loss and steatorrhea. Its presence is suspected on clinical ground and can be supported by fecal elastase-1 measurement. Exocrine insufficiency can be compensated with oral enteric-coated enzyme supplements. The quality of life issue will be addressed as an important outcome measurement after pancreaticoduodenectomy. Furthermore,
\end{abstract}

the functional changes after pancreatoduodenectomy are described in detail with suggestions for diagnosis and treatment.

Copyright $\odot 2010$ S. Karger AG, Basel and IAP

\section{Introduction}

Surgery is the cornerstone of treatment with curative intention for patients with tumors of the pancreatic head and the periampullar region. Radical resection by means of pancreatoduodenectomy offers the only chance for cure. Partial pancreatoduodenectomy was introduced in the beginning of the 20th century by Codivilla and Kausch. A modification of the classical partial pancreatoduodenectomy as popularized by Whipple et al. [1] is the pylorus-preserving pancreatoduodenectomy (PPPD), first described by Watson [2] in 1944. Preserving the pylorus is thought to have various advantages, such as simplification of the operation and improvement of postoperative gastrointestinal function without any negative oncological consequences for the patient [3]. To date, three randomized studies compared the classic Whipple's operation with PPPD. Two relatively small studies reported that the pylorus-preserving procedure was associated with shorter operation time, less blood loss, less blood transfusion and a lower morbidity rate in comparison to the classic Whipple procedure $[4,5]$. In contrast, our own

\section{KARGER \\ Fax +4161306 1234 \\ E-Mail karger@karger.ch}

www.karger.com
(C) 2010 S. Karger AG, Basel and IAP

1424-3903/09/0096-0729\$26.00/0

Accessible online at:

www.karger.com/pan
T.C.K. Tran

Department of Surgery

Erasmus Medical Center, 's Gravendijkwal 230

NL-3015 CE Rotterdam (The Netherlands)

Tel. +31 104633 854, Fax +31 104633 350, E-Mail t.tran@erasmusmc.nl 
Table 1. Functional changes of the stomach, duodenum and pancreas after pancreatoduodenectomy

\begin{tabular}{|c|c|c|c|c|}
\hline Functional changes & Incidence & Presentation & Diagnosis & Treatment \\
\hline \multicolumn{5}{|l|}{ Stomach } \\
\hline Delayed gastric emptying & $15-40 \%$ & $\begin{array}{l}\text { nasogastric tube }>10 \text { days } \\
\text { inability to tolerate a regular } \\
\text { diet } \geq 14 \text { th day p.o. }\end{array}$ & $\begin{array}{l}\text { gastric emptying } \\
\text { scintigraphy }\end{array}$ & $\begin{array}{l}\text { recovery } \\
<6 \text { months } \\
\text { erythromycin }{ }^{\circledR}\end{array}$ \\
\hline \multicolumn{5}{|l|}{ Duodenum } \\
\hline$\downarrow$ Pancreas-stimulating hormones & $100 \%$ & altered digestion process & failure to thrive & symptomatic \\
\hline Peptic ulcer formation & $<5 \%$ & & & $\begin{array}{l}\text { proton pump } \\
\text { inhibitors }\end{array}$ \\
\hline \multicolumn{5}{|l|}{ Pancreas } \\
\hline Diabetes mellitus & $20-40 \%$ & hyperglycemia & $\begin{array}{l}\downarrow \text { glucagon } \\
\uparrow \text { insuline insensitivity }\end{array}$ & $\begin{array}{l}\text { hormonal } \\
\text { regulation }\end{array}$ \\
\hline Exocrine insufficiency & unknown & algorithm figure 1 & figure 1 & figure 1 \\
\hline
\end{tabular}

randomized multicenter study [6] found no difference between both procedures in operation time, blood loss, delayed gastric emptying, hospitalization time, or overall survival rate.

In spite of the still relatively high morbidity resulting from the extensive and invasive surgical procedure, pancreatoduodenectomy is increasingly being performed. This is partly because of a considerable reduction in perioperative mortality. In high-volume centers, a mortality rate of less than $2 \%$ has been reported [7-12]. Because of these advances, the assessment and improvement of short- and long-term postoperative quality of life have become important topics. Many publications have reported on quality of life issues after pancreatoduodenectomy [2, 13-18]. However, relatively little is known about the gastrointestinal function after recovery of a pancreatoduodenectomy.

This review focuses on the functional changes of the stomach, duodenum and pancreas that occur after pancreatoduodenectomy. The various factors and mechanisms that are involved will be described with recommendations for diagnosis and treatment.

In table 1, a summary is given of the functional changes of the stomach, duodenum and pancreas after pancreatoduodenectomy.

\section{Changes in Gastric Function}

Delayed gastric emptying (DGE) is a leading cause of morbidity after pancreatoduodenectomy, occurring early after the surgical procedure with an estimated inci- dence between 15 and 40\%. DGE is defined as gastric stasis requiring nasogastric intubation for ten days or more or the inability to tolerate a regular diet on the 14th postoperative day [19]. Whether or not the pylorus is preserved does not seem to have a great impact in the occurrence of delayed gastric emptying [6]. There is a decrease in the subjective perception of the occurrence of belching and nausea after Whipple's operation due to the absence of mechanoreceptors as a result of the partial stomach resection [20]. Other causes of DGE after pancreatoduodenectomy are the presence of peritonitis as a result of postoperative complications such as intra-abdominal abscesses, leakage of the pancreatojejunostomy, ischemia of the antropyloric muscles and reoperation $[21,22]$. Objective quantification of DGE is difficult. In daily practice, gastric scintigraphy is the preferred method to determine DGE. For this purpose, technetium (20 MBq ${ }^{99 m}$ hepatate) labeled semi-solids or a technetium $\left(20 \mathrm{MBq}{ }^{99 \mathrm{~m} T c-}\right.$ pertechnetate) labeled pancake are used. Normal halfemptying time varies between 38 and $83 \mathrm{~min}$ after intake. In general, this investigation is considered too time consuming and too much of a burden for patients in the early postoperative phase and a presumptive diagnosis is usually made on clinical grounds.

Naritomi et al. [23] showed that a low serum level of motilin delays gastric passage in these patients. In a randomized, placebo-controlled study of 118 consecutive patients undergoing a pancreatoduodenectomy, Yeo et al. [24] have shown that the administration of erythromycin, which has not only antimicrobial but also prokinetic activity, stimulates gastric evacuation. They found a significantly reduced need to reinsert a nasogastric tube and a 
significantly reduced retention of liquids in the group of patients that was treated with erythromycin. Besides erythromycin, most commonly used prokinetics are metoclopramide, domperidon and cisapride with variable clinical relief of symptoms. The value of new prokinetics, including mosapride citrate (a selective agonist for 5-hydroxytryptamine- 4 receptors), itopride hydrochloride (a benzamide derivative with both dopamin $\mathrm{D} 2$ receptor antagonism and acetylcholinesterase inhibition) and GM611 (an erythromycin-derived motilin agonist) has not yet been fully investigated and therefore these drugs are not yet regularly used in clinical practice. In general, the gastric emptying function gradually recovers spontaneously to the preoperative level by 6 months after PPPD.

\section{Changes in Duodenal Function}

With the resection of the largest part of the duodenum, the major digestive processes are disturbed and the delicately controlled digestive chain between the stomach, duodenum and pancreatobiliary secretions is disrupted. A reduced production of pancreas-stimulating hormones such as gastrin, cholecystokinin (CCK) and secretin leads to an inadequate pancreatic secretion of bicarbonate. As a result, the gastric content is not neutralized to an optimal $\mathrm{pH}$. Furthermore, a reduced production of enterokinase by the duodenum leads to an inadequate activation of pancreatic proteolytic, amylolytic and lipolytic enzymes.

As mentioned before, resection of the pancreatic head and duodenum results in a decrease in pancreas bicarbonate secretion and inadequate gastric acid neutralization. Excretion of this bicarbonate-poor fluid in the remnant of the duodenum stimulates the development of ulcerations. However, peptic ulcers occur in less than $5 \%$ of patients after pancreatic surgery [25]. A possible explanation could be the frequent use of octreotide and protonpomp inhibitors postoperatively, although controversies remain regarding their use after a pancreatoduodenectomy.

\section{Changes in Endocrine Pancreatic Function}

The more extended the resection of the pancreas, the greater the risk of endocrine (and exocrine) pancreatic insufficiency.

The incidence of diabetes mellitus after a pancreatic resection varies between 20 and 50\% [26], with some pa- tients already suffering from diabetes preoperatively and a number of patients developing diabetes de novo.

Controversy remains whether diabetes is a risk factor for the development of pancreatic cancer or whether pancreatic cancer causes diabetes. There are compelling data that long-standing diabetes might increase the risk of pancreatic cancer [27-30]. However, in simple cross-sectional studies (recent-onset) diabetes is frequently diagnosed in combination with pancreatic cancer. This is an argument against preexisting diabetes mellitus being a risk factor for pancreatic cancer. Probably, these observations can neither be fully explained by destruction of the endocrine pancreas, but rather seem to be partly the result of a remote effect of the tumor causing impaired glucose metabolism. An interesting clinical observation is the fact that in some patients the diabetes disappears postoperatively [31].

On the other hand, preoperative obstruction of the pancreatic duct is associated with the development of diabetes mellitus as a result of destruction of the parenchyma [32]. In our own experience [33] patients with an iatrogenic pancreatic duct occlusion during a pancreatoduodenectomy develop significantly more diabetes mellitus in comparison to those who had a pancreatojejunal anastomosis.

The type of glucose intolerance which results from pancreatic resection is termed pancreatogenic diabetes. It is associated with features distinct from both type I (insulin-dependent) and type II (insulin-independent, or adult-onset) diabetes [34].

Hepatic insulin resistance with persistent endogenous glucose production and enhanced peripheral insulin sensitivity results in a brittle form of diabetes, which can be difficult to manage. Surprisingly, pancreatogenic diabetes is characterized by a decrease in hepatic insulin receptor availability and an increase in peripheral insulin receptor availability [35]. This paradoxical effect is probably due to the concurrent deficiency in pancreatic polypeptide and renders the liver resistant to the suppressant effects of insulin on hepatic glucose production. The result of increased hepatic glucagon responsiveness and diminished hepatic insulin responsiveness is elevated (or unsuppressed) endogenous glucose production, which in turn results in hyperglycemia together with an enhanced hypoglycemic response to exogenous insulin in patients with pancreatogenic diabetes. 


\section{Assessment of Endocrine Pancreatic Function}

Diabetes mellitus is defined as a fasting glucose concentration $\geq 7.0 \mathrm{mmol} / \mathrm{l}$ or a random glucose value $\geq 11$ $\mathrm{mmol} / \mathrm{l}[36]$ or a GTT (glucose tolerance test) level $\geq 11$ $\mathrm{mmol} / \mathrm{l}$ after $2 \mathrm{~h}$.

\section{Treatment of Endocrine Pancreatic Insufficiency}

Usually, the treatment of patients with diabetes starts with diet, weight reduction, and exercise. After a pancreatic resection most patients already suffer from maldigestion problems.

Patients with persistent hyperglycemia are often started on one or more oral hypoglycemic drugs. Insulin is added if target level of glucose is not attained. Patients with pancreatogenic diabetes behave differently compared to other diabetics with respect to insulin therapy. These 'brittle diabetics' may become unpredictably hypoglycemic during maintenance insulin therapy, unrelated to meals or exercise. The need for insulin depends upon the delicate balance between insulin secretion, insulin resistance and glucagon responsiveness.

\section{Changes in Exocrine Pancreatic Function}

From the scant data that are available to date, it is difficult to provide an overview of the risk of exocrine insufficiency and the success or failure rate of supplementation therapy. The pathophysiology is complex and comprises factors such as preoperative exocrine pancreatic function and the chosen surgical procedure of resection and restoration of gastrointestinal tract continuity.

In general, the functional reserve of exocrine pancreatic functions ensures that insufficiency occurs only during the course of illness. Up to $90-95 \%$ of the pancreatic enzyme output may be lost before clinical signs of exocrine insufficiency develop [37].

The most frequently described change in exocrine pancreatic function after pancreatoduodenectomy is reduced digestion of fat which leads to weight loss, nutrient deficiency and subjective complaints consistent with steatorrhea [38]. It is extremely difficult to appreciate and unravel the impact of each individual factor that contributes to the postsurgical maldigestion.

Most of the data on exocrine pancreatic insufficiency after pancreatic surgery arise from studies in patients with chronic pancreatitis. This group of patients is known to develop exocrine pancreatic insufficiency frequently in the course of their illness due to destruction of acinar cells with replacement of the parenchyma by fibrous tissue. Deterioration of the exocrine function often occurs after pancreatic surgery, partly depending on the extensiveness of resection.

Another important factor regarding the exocrine function is whether the pancreatoduodenectomy is combined with a partial resection of the stomach. First of all there is an inadequate grinding of food particles. Secondly, a reduced secretion of secretin and CCK results in a reduced production of bicarbonate-rich fluid and digestive enzymes, such as amylase, lipase and trypsinogen, which are important for the continuation of the digestion. Finally, the resection of the pancreatic parenchyma also contributes to a decreased production of pancreatic juices, leading to maldigestion and malabsorption of nutrients postoperatively.

Although compensatory hypertrophy of the pancreatic remnant with increased enzyme production has been observed in animal research, this is hardly ever sufficient to compensate for the induced exocrine insufficiency in the clinical setting.

The type of reconstruction after pancreatoduodenectomy also appears to affect the occurrence of exocrine loss of function. In some studies [39] a pancreatogastrostomy is described to cause further deterioration of the exocrine insufficiency as a result of accelerated inactivation of pancreatic enzymes by gastric juices.

\section{Assessment of Exocrine Pancreatic Function}

A number of different exocrine pancreatic function tests are available [40]. The secretin-cerulein intubation test is often used as the 'gold standard'. This test involves the collection of gastric juices after intravenous administration of secretin and measurement of luminal bicarbonate and protein levels. However, it is difficult or even impossible to perform postoperatively. Much less elaborate are indirect nonintubation function tests with administration of a pancreatic enzyme supplement and the measurement of the enzymatic breakdown of intraluminally administered products. The most widely used tests for this purpose are the bentiromide or N-benzoyl-L-tyrosyl- $p$-aminobenzoic acid test (BT-PABA/PAS test) and the pancreolauryl (fluorescein dilaurate) test. In the bentiromide test, bentiromide is broken down by chymotripsin into $p$-aminobenzoe acid and aminobenzoate acid, which is absorbed and secreted by the urine. However, 
Fig. 1. Algorithm for the diagnosis and treatment of exocrine pancreatic insufficiency. * Pancreatine preparations: start with 25,000-50,000 IU lipase during main meal and 10,000-25,000 IU lipase during in-between snacks.

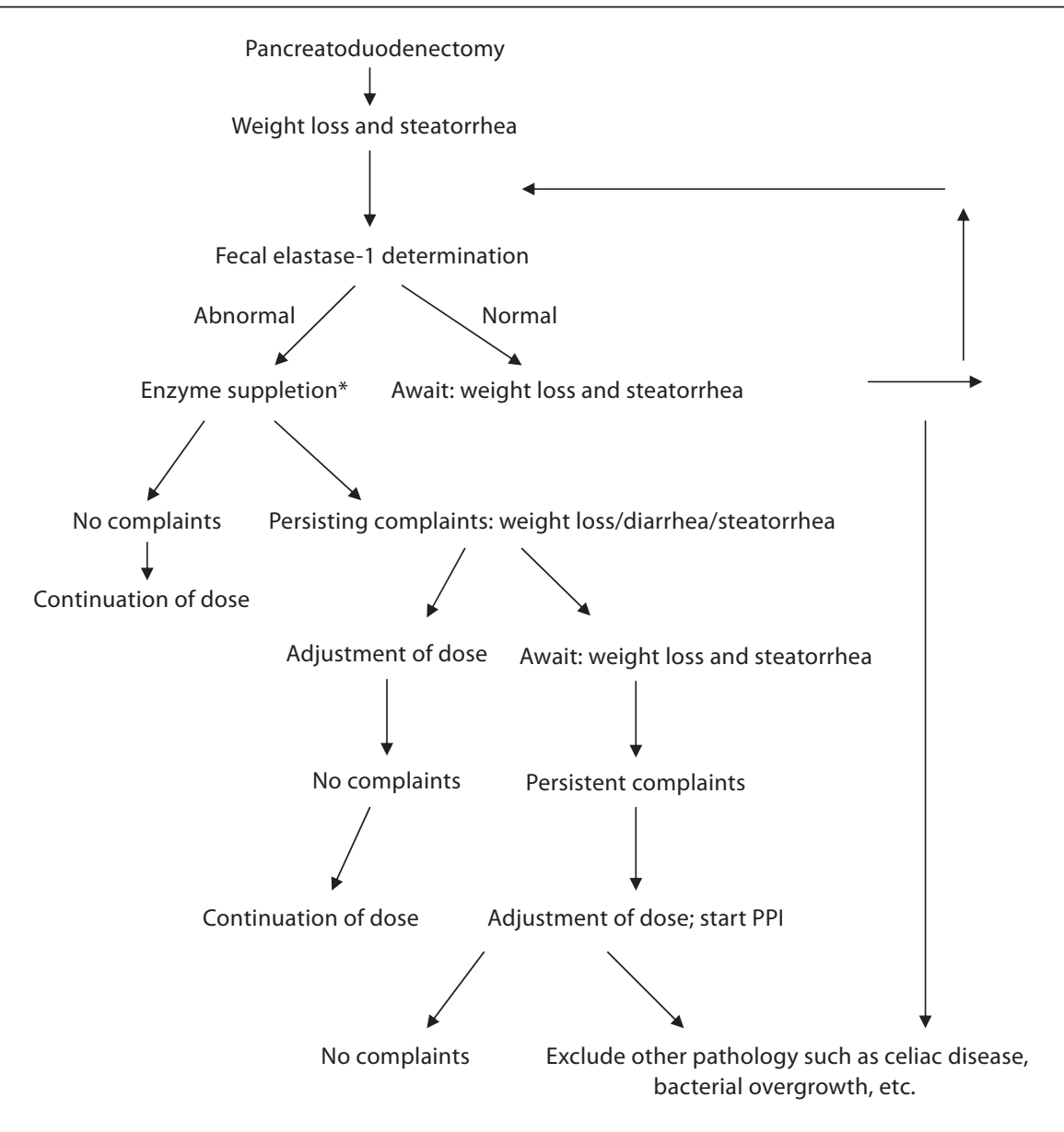

false-positive test results (i.e. exocrine pancreatic insufficiency is falsely diagnosed) may occur in cases of poor absorption due to intestinal resection, delayed gastric emptying or rapid intestinal transit. In the pancreolauryl test, fluorescein dilaurate is administered, which is also absorbed and secreted by the urine. Preexisting liver disease, renal insufficiency and malabsorption syndromes can induce false-positive results.

For clinical practice, the fecal elastase- 1 test is an effective test for the evaluation of exocrine pancreatic insufficiency [41-44]. This test has a number of advantages. First, the enzyme is not degraded during intestinal transport; secondly, elastase is concentrated in the feces, and, finally, the enzyme is easily detected by means of an ELISA test. Especially during the initial phase of exocrine pancreatic insufficiency this test shows high sensitivity and specificity. Another advantage of this test is the fact that the results are not affected by the use of enzyme suppletion therapy.
The cholesteryl $\left[{ }^{14} \mathrm{C}\right]$ octanoate breath test is also a suitable indirect test for this purpose $[45,46]$. The test is based on the intraluminal hydrolysis of cholesteryl $-{ }^{14} \mathrm{C}$ octanoate by pancreatic cholesterol esterase and the subsequent absorption and rapid metabolization of ${ }^{14} \mathrm{C}$-octanoic acid to ${ }^{14} \mathrm{CO}_{2}$. Measurement of ${ }^{14} \mathrm{CO}_{2}$ in breath allows an indirect estimation of intraluminal hydrolytic activity and its time course. Only pancreas-specific enzyme activity is measured since intraluminal activity of cholesterol esterase is of pancreatic origin only.

\section{Treatment of Exocrine Pancreatic Insufficiency}

In clinical practice, it is recommended to supplement pancreas enzymes after any form of pancreatic resection. In several studies [47-52] the enteric-coated (mini-)microspheres are generally the preferred pharmacological formulation of pancreatic enzymes. The coating with a $\mathrm{pH}$ sensitive polyacryl acid layer, which only dissolves at 
a $\mathrm{pH}$ level $>5.5$, maintains the enzyme integrity in the stomach and therefore improves the efficacy of the enzyme supplements. For this reason, the use of a proton pump inhibitor postoperatively also helps to increase the $\mathrm{pH}$ in the proximal small intestine, aiding to achieve a rapid and proximal release of pancreatic enzymes from the enteric coat. The coating also masks the unpleasant taste of these enzymes. However, one should keep in mind that in patients who already suffer from impaired digestion due to the partial gastric resection, the duodenum resection and the jejunal reconstruction, the enzyme release from these enteric-coated preparations will be too slow and therefore the efficacy will decrease. Therefore, in order to obtain an optimal therapeutic effect, it is recommended to administrate oral enzymes just after the meals, or even better, distributed along with meals [53].

In figure 1 an algorithm is suggested for diagnosis and treatment of pancreatic exocrine insufficiency.

\section{Quality of Life}

Quality of life (QoL) is an important outcome measure after pancreatic resection for malignancy because various surgical approaches aimed at prolonged survival can have a great impact on patient performance.

Although many studies have addressed the QoL issue, it is difficult to compare QoL results because of differences in methods, study designs and patients characteristics in these studies. The instruments used for QoL assessment range from visual analogue scales, standardized health care-related questionnaires in combination with a standard Functional Assessment of Cancer Therapy Hepatobiliary QoL survey [13] to an EORTC QLQ C30 core questionnaire [16] in combination with a disease-specific Gastrointestinal QoL index [15, 18]. Most studies revealed a large decrease in most QoL scales immediately after surgery followed by a slow recovery to preoperative level by 12-24 months after surgery. The surgical techniques of resection and reconstruction do not seem to affect QoL. From a recent study by Morak et al. (paper accepted in June 2009 for Cancer), comparing QoL in patients receiving celiac axis infusion chemotherapy/radiotherapy (CAI/RT) after pancreatoduodenectomy with QoL in patients without adjuvant treatment, they found that over a period of 24 months, CAI/RT improved quality of life compared to observation alone in patients with resected pancreatic and periampullary cancer. However, these studies contain no information on patients who were operated with a palliative intention.

\section{Proposal for Diagnostic and Therapeutic Approach of Pancreatic Insufficiency}

In all patients with a condition involving the pancreas, we recommend a fasting glucose level and fecal elastase-1 determination at onset. If the results are abnormal one can start treatment with hormonal regulation and enzyme supplementation.

Apart from decreased insulin production, the increase in insulin insensitivity combined with the decrease in glucagon production may play an important part in these patients. Therefore, postoperative monitoring of the glucose level is of great importance in order to treat endocrine pancreatic insufficiency adequately.

Enzyme supplementation can be started directly after resuming oral intake postoperatively. The recommended start doses of pancreatine capsules are 25,000 to 50,000 IU lipase during a main meal and 10,000 to 25,000 IU lipase during in-between snacks. For an optimal mixture of food and enzymes, the ingestion of enzymes should be divided over the meal. The efficacy of treatment is evaluated by means of repeated measurements of body weight and history takings of steatorrhea-associated complaints.

Persistent weight loss and steatorrhea are indications of an inadequate compensation of the exocrine pancreatic insufficiency. In case of an insufficient treatment response, the dosis should be increased and/or a protonpump inhibitor should be started. In treatment-resistant cases other diagnosis such as celiac disease or bacterial overgrowth should be considered. The efficacy of treatment is evaluated by means of repeated measurements of body weight and history takings of steatorrhea-associated complaints. The cholesteryl $\left[{ }^{14} \mathrm{C}\right]$ octanotate breath test can be used for monitoring.

\section{Conclusion}

Motility disorders and endocrine and exocrine pancreatic insufficiency are frequently encountered after pancreatoduodenectomies. The resulting symptoms have a substantial impact on the patient's quality of life. Now that the postoperative mortality after pancreatoduodenectomy has substantially decreased, more attention should be focussed on the diagnosis and treatment of the functional consequences after pancreatoduodenectomy. For this purpose, we have indicated a practical guideline. 


\section{T.C. Khe Tran, MD}

Currently: Gastrointestinal and Transplant Surgeon, Department of Surgery, Erasmus MC, Rotterdam, The Netherlands

Fellowship Gastrointestinal Surgery: Erasmus MC, Rotterdam,

The Netherlands

Residency: University Hospital-St Radboud, Nijmegen, The Netherlands

\section{Jan J.B. van Lanschot, MD, PhD}

Currently: Professor and Chairman, Department of Surgery, Erasmus MC, Rotterdam, The Netherlands.

Previously: Professor of Surgical Oncology, AMC, Amsterdam,

The Netherlands

Research Fellowship: Brigham \& Women's Hospital, Harvard Medical School, Boston, Mass., USA

Residency: University Hospital-Dijkzigt, Rotterdam, The Netherlands

\section{Marco J. Bruno, MD, PhD}

Marco J. Bruno was trained at the Department of Gastroenterology and Hepatology at the Academic Medical Center (AMC) in Amsterdam under the supervision of Guido Tytgat. His PhD thesis focused on the efficacy of enzyme replacement therapy in exocrine pancreatic insufficiency. After his training, he continued his career as a staff member specializing in the area of hepatopancreato-biliary diseases and advanced interventional endoscopy, including ERCP and EUS. In March 2008, he changed positions and moved to the Department of Gastroenterology and Hepatology of the Erasmus Medical Center (EMC) in Rotterdam. He is Director of Endoscopy. His clinical and research activities focus on gastrointestinal oncology and interventional endoscopy, and he has a special interest in pancreatic diseases. He has published in many peer-reviewed medical journals, has been a speaker at numerous international symposia and congresses, and has contributed to various international live endoscopy workshops.
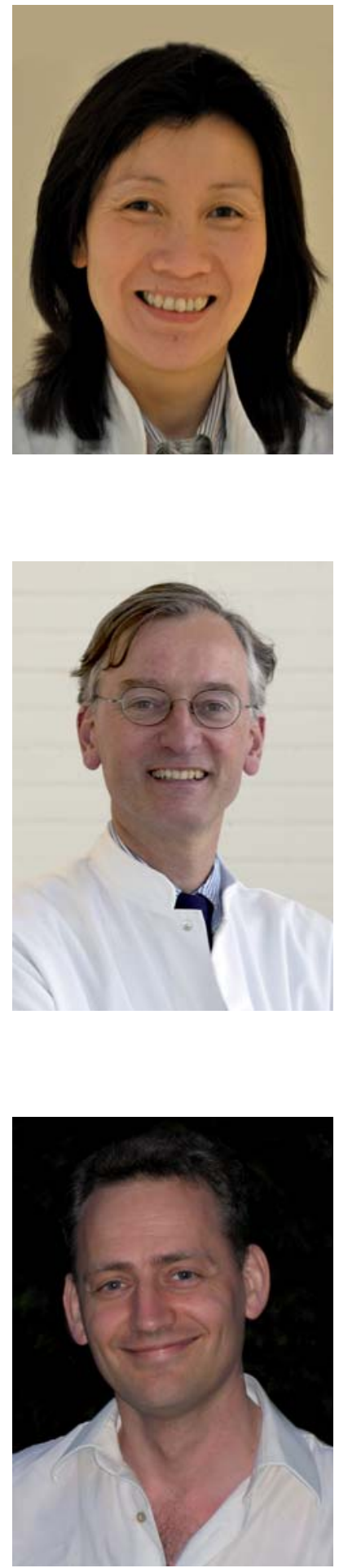


\section{Casper H.J. van Eijck, MD, PhD}

Casper H.J. van Eijck was born January 9th 1957 in Rotterdam, The Netherlands. He studied medicine at the Erasmus University from 1977 till 1984. He started his surgical residency in 1985 in at the Leyenburg Hospital in The Hague and after 4 years he finished his residency at the Erasmus Medical Center in Rotterdam in 1991. He presented his thesis 'The Role of Somatostatin Receptors in Breast and Pancreatic Cancer' in 1993. He is working at the Erasmus Medical Center and specializes in endocrine and pancreatobiliary surgery. He became Professor in Surgery in 2009.

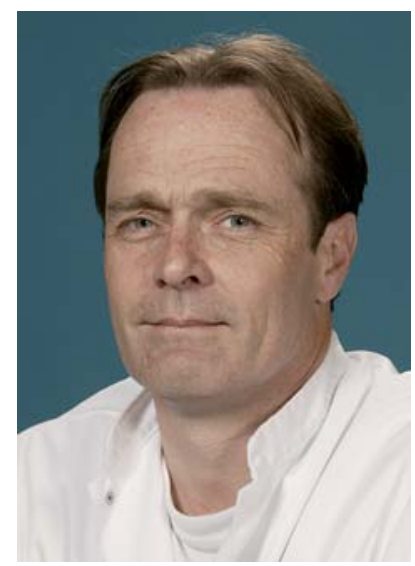

\section{References}

1 Whipple AO, Parson WB, Mullins CR: Treatment of carcinoma of the ampulla of vater. Ann Surg 1935;102:763-779.

$\checkmark 2$ Watson K: Carcinoma of the ampulla of vater: successful radical resection. Br J Surg 1944;31:368-373.

3 Klinkenbijl JH, van der Schelling GP, Hop WC, van Pel R, Bruining HA, Jeekel J: The advantages of pylorus-preserving pancreatoduodenectomy in malignant disease of the pancreas and periampullary region. Ann Surg 1992;216:142-145.

$\checkmark 4$ Lin PW, Lin YJ: Prospective randomized comparison between pylorus-preserving and standard pancreaticoduodenectomy. $\mathrm{Br}$ J Surg 1999;86:603-607.

5 Seiler CA, Wagner M, Sadowski C, Kulli C, Buchler MW: Randomized prospective trial of pylorus-preserving vs. classic duodenopancreatectomy (Whipple procedure): initial clinical results. J Gastrointest Surg 2000; 4:443-452.

-6 Tran KT, Smeenk HG, van Eijck CH, Kazemier G, Hop WC, Greve JW, Terpstra OT, Zijlstra JA, Klinkert P, Jeekel H: Pylorus preserving pancreaticoduodenectomy versus standard whipple procedure: a prospective, randomized, multicenter analysis of $170 \mathrm{pa}-$ tients with pancreatic and periampullary tumors. Ann Surg 2004;240:738-745.

7 Birkmeyer JD, Siewers AE, Finlayson EV, Stukel TA, Lucas FL, Batista I, Welch HG, Wennberg DE: Hospital volume and surgical mortality in the United States. N Engl J Med 2002;346:1128-1137.

-8 Birkmeyer JD, Stukel TA, Siewers AE, Goodney PP, Wennberg DE, Lucas FL: Surgeon volume and operative mortality in the United States. N Engl J Med 2003;349:21172127.
9 Birkmeyer JD, Dimick JB, Staiger DO: Operative mortality and procedure volume as predictors of subsequent hospital performance. Ann Surg 2006;243:411-417.

10 Gouma DJ, van Geenen RC, van Gulik TM, de Haan RJ, de Wit LT, Busch OR, Obertop $\mathrm{H}$ : Rates of complications and death after pancreaticoduodenectomy: risk factors and the impact of hospital volume. Ann Surg 2000;232:786-795.

11 van Heek NT, Kuhlmann KF, Scholten RJ, de Castro SM, Busch OR, van Gulik TM, Obertop H, Gouma DJ: Hospital volume and mortality after pancreatic resection: a systematic review and an evaluation of intervention in the Netherlands. Ann Surg 2005;242:781788; discussion 788-790.

12 Winter JM, Cameron JL, Campbell KA, Arnold MA, Chang DC, Coleman J, Hodgin MB, Sauter PK, Hruban RH, Riall TS, Schulick RD, Choti MA, Lillemoe KD, Yeo CJ: 1423 pancreaticoduodenectomies for pancreatic cancer: a single-institution experience. J Gastrointest Surg 2006;10:1199-1210; discussion 1210-1191.

13 Nguyen TC, Sohn TA, Cameron JL, Lillemoe KD, Campbell KA, Coleman J, Sauter PK, Abrams RA, Hruban RH, Yeo CJ: Standard vs. radical pancreaticoduodenectomy for periampullary adenocarcinoma: a prospective, randomized trial evaluating quality of life in pancreaticoduodenectomy survivors. J Gastrointest Surg 2003;7:1-9; discussion 9-11.

14 Nieveen Van Dijkum EJ, Terwee CB, Oosterveld P, Van Der Meulen JH, Gouma DJ, De Haes JC: Validation of the gastrointestinal quality of life index for patients with potentially operable periampullary carcinoma. Br J Surg 2000;87:110-115.
15 Nieveen van Dijkum EJ, Kuhlmann KF, Terwee CB, Obertop H, de Haes JC, Gouma DJ: Quality of life after curative or palliative surgical treatment of pancreatic and periampullary carcinoma. Br J Surg 2005;92:471-477.

16 Schniewind B, Bestmann B, Henne-Bruns D, Faendrich F, Kremer B, Kuechler T: Quality of life after pancreaticoduodenectomy for ductal adenocarcinoma of the pancreatic head. Br J Surg 2006;93:1099-1107.

17 Schniewind B, Bestmann B, Kurdow R, Tepel J, Henne-Bruns D, Faendrich F, Kremer B, Kuechler T: Bypass surgery versus palliative pancreaticoduodenectomy in patients with advanced ductal adenocarcinoma of the pancreatic head, with an emphasis on quality of life analyses. Ann Surg Oncol 2006;13: 1403-1411

18 Witzigmann H, Max D, Uhlmann D, Geissler F, Schwarz R, Ludwig S, Lohmann T, Caca K, Keim V, Tannapfel A, Hauss J: Outcome after duodenum-preserving pancreatic head resection is improved compared with classic Whipple procedure in the treatment of chronic pancreatitis. Surgery 2003;134:5362.

19 van Berge Henegouwen MI, van Gulik TM, DeWit LT, Allema JH, Rauws EA, Obertop H, Gouma DJ: Delayed gastric emptying after standard pancreaticoduodenectomy versus pylorus-preserving pancreaticoduodenectomy: an analysis of 200 consecutive patients. J Am Coll Surg 1997;185:373-379.

20 Shan YS, Sy ED, Tsai ML, Tang LY, Li PS, Lin PW: Effects of somatostatin prophylaxis after pylorus-preserving pancreaticoduodenectomy: increased delayed gastric emptying and reduced plasma motilin. World J Surg 2005;29:1319-1324. 
-21 Kamiya T, Kobayashi Y, Hirako M, Misu N, Nagao T, Hara M, Matsuhisa E, Ando T, Adachi H, Sakuma N, Kimura G: Gastric motility in patients with recurrent gastric ulcers. J Smooth Muscle Res 2002;38:1-9.

-22 Kimura F, Suwa T, Sugiura T, Shinoda T, Miyazaki M, Itoh $\mathrm{H}$ : Sepsis delays gastric emptying following pylorus-preserving pancreaticoduodenectomy. Hepatogastroenterology 2002;49:585-588.

-23 Naritomi G, Tanaka M, Matsunaga H, Yokohata K, Ogawa Y, Chijiiwa K, Yamaguchi K: Pancreatic head resection with and without preservation of the duodenum: different postoperative gastric motility. Surgery 1996; 120:831-837.

-24 Yeo CJ, Barry MK, Sauter PK, Sostre S, Lillemoe KD, Pitt HA, Cameron JL: Erythromycin accelerates gastric emptying after pancreaticoduodenectomy: a prospective, randomized, placebo-controlled trial. Ann Surg 1993;218:229-237; discussion 237-228.

25 Grace PA, Pitt HA, Longmire WP: Pancreatoduodenectomy with pylorus preservation for adenocarcinoma of the head of the pancreas. Br J Surg 1986;73:647-650.

-26 Stone WM, Sarr MG, Nagorney DM, McIlrath DC: Chronic pancreatitis: results of whipple's resection and total pancreatectomy. Arch Surg 1988;123:815-819.

27 Everhart J, Wright D: Diabetes mellitus as a risk factor for pancreatic cancer: a metaanalysis. JAMA 1995;273:1605-1609.

28 Fisher WE: Diabetes: risk factor for the development of pancreatic cancer or manifestation of the disease? World J Surg 2001;25: 503-508.

29 Gullo L, Pezzilli R, Morselli-Labate AM: Diabetes and the risk of pancreatic cancer. $\mathrm{N}$ Engl J Med 1994;331:81-84.

-30 Yalniz M, Pour PM: Diabetes mellitus: a risk factor for pancreatic cancer? Langenbecks Arch Surg 2005;390:66-72.

-31 Murphy R, Smith FH: Abnormal carbohydrate metabolism in pancreatic carcinoma. Med Clin North Am 1963;47:397-405.

- 32 Ohshio G, Tanaka T, Imamura T, Okada N, Yoshitomi S, Suwa H, Hosotani R, Imamura M: Exocrine pancreatic function in the early period after pancreatoduodenectomy and effects of preoperative pancreatic duct obstruction. Dig Dis Sci 1996;41:1947-1952.
33 Tran K, Van Eijck C, Di Carlo V, Hop WC, Zerbi A, Balzano G, Jeekel H: Occlusion of the pancreatic duct versus pancreaticojejunostomy: a prospective randomized trial. Ann Surg 2002;236:422-428; discussion 428.

34 Slezak LA, Andersen DK: Pancreatic resection: effects on glucose metabolism. World J Surg 2001;25:452-460.

35 Seymour J: Diabetes blood glucose monitoring. Nurs Times 1995;91:46-49.

36 Genuth S, Alberti KG, Bennett P, Buse J, Defronzo R, Kahn R, Kitzmiller J, Knowler WC Lebovitz H, Lernmark A, Nathan D, Palmer J, Rizza R, Saudek C, Shaw J, Steffes M, Stern M, Tuomilehto J, Zimmet P: Follow-up report on the diagnosis of diabetes mellitus. Diabetes Care 2003;26:3160-3167.

37 DiMagno EP: Medical treatment of pancreatic insufficiency. Mayo Clin Proc 1979;54: 435-442.

38 Layer P, Keller J: Pancreatic enzymes: secretion and luminal nutrient digestion in health and disease. J Clin Gastroenterol 1999;28: 3-10.

-39 Jang JY, Kim SW, Han JK, Park SJ, Park YC Joon Ahn Y, Park YH: Randomized prospective trial of the effect of induced hypergastrinemia on the prevention of pancreatic atrophy after pancreatoduodenectomy in humans. Ann Surg 2003;237:522-529.

40 Steer ML, Waxman I, Freedman S: Chronic pancreatitis. N Engl J Med 1995;332:14821490.

41 Beharry S, Ellis L, Corey M, Marcon M, Durie $\mathrm{P}$ : How useful is fecal pancreatic elastase 1 as a marker of exocrine pancreatic disease? J Pediatr 2002;141:84-90.

42 Carroccio A, Verghi F, Santini B, Lucidi V, Iacono G, Cavataio F, Soresi M, Ansaldi N, Castro M, Montalto G: Diagnostic accuracy of fecal elastase 1 assay in patients with pancreatic maldigestion or intestinal malabsorption: a collaborative study of the italian society of pediatric gastroenterology and hepatology. Dig Dis Sci 2001;46:1335-1342.

43 Gullo L, Ventrucci M, Tomassetti P, Migliori M, Pezzilli R: Fecal elastase 1 determination in chronic pancreatitis. Dig Dis Sci 1999;44: 210-213.

44 Stein J, Jung M, Sziegoleit A, Zeuzem S, Caspary WF, Lembcke B: Immunoreactive elastase I: clinical evaluation of a new noninvasive test of pancreatic function. Clin Chem $1996 ; 42: 222-226$
45 Bruno MJ, Hoek FJ, Delzenne B, van Leeuwen DJ, Schteingart CD, Hofmann AF, Tytgat GN: Simultaneous assessments of exocrine pancreatic function by cholesteryl$\left[{ }^{14} \mathrm{C}\right]$ octanoate breath test and measurement of plasma $p$-aminobenzoic acid. Clin Chem 1995;41:599-604.

46 Mundlos S, Kuhnelt P, Adler G: Monitoring enzyme replacement treatment in exocrine pancreatic insufficiency using the cholesteryl octanoate breath test. Gut 1990;31:13241328 .

47 Adler G, Mundlos S, Kuhnelt P, Dreyer E: New methods for assessment of enzyme activity: do they help to optimize enzyme treatment? Digestion 1993;54(suppl 2):3-9.

-48 Bruno MJ, Borm JJ, Hoek FJ, Delzenne B, Hofmann AF, de Goeij JJ, van Royen EA, van Gulik TM, de Wit LT, Gouma DJ, van Leeuwen DJ, Tytgat GN: Comparative effects of enteric-coated pancreatin microsphere therapy after conventional and pylorus-preserving pancreatoduodenectomy. Br J Surg 1997; 84:952-956.

-49 Dutta SK, Rubin J, Harvey J: Comparative evaluation of the therapeutic efficacy of a phsensitive enteric coated pancreatic enzyme preparation with conventional pancreatic enzyme therapy in the treatment of exocrine pancreatic insufficiency. Gastroenterology 1983;84:476-482.

50 Graham DY: An enteric-coated pancreatic enzyme preparation that works. Dig Dis Sci 1979;24:906-909.

51 Lankisch PG, LembckeB, GokeB, Creutzfeldt W: Therapy of pancreatogenic steatorrhoea: does acid protection of pancreatic enzymes offer any advantage? Z Gastroenterol 1986; 24:753-757.

-52 Schneider MU, Knoll-Ruzicka ML, Domschke S, Heptner G, Domschke W: Pancreatic enzyme replacement therapy: comparative effects of conventional and enteric-coated microspheric pancreatin and acid-stable fungal enzyme preparations on steatorrhoea in chronic pancreatitis. Hepatogastroenterology 1985;32:97-102.

53 Dominguez-Munoz JE, Iglesias-Garcia J, Iglesias-Rey M, Figueiras A, Vilarino-Insua M: Effect of the administration schedule on the therapeutic efficacy of oral pancreatic enzyme supplements in patients with exocrine pancreatic insufficiency: a randomized, three-way crossover study. Aliment Pharmacol Ther 2005;21:993-1000. 